Journal of History Culture and Art Research (ISSN: 2147-0626)

Tarih Kültür ve Sanat Araştırmaları Dergisi

Vol. 9, No. 4, December 2020

\title{
DOI: 10.7596/taksad.v9i4.2784
}

Citation: Drozdovskyi, D., Ivanyshyn, P., \& Prykhodko, O. (2020). The Irish Experience of Identity Representation: M. J. Hyland's "Carry Me Down”. Journal of History Culture and Art Research, 9(4), 262-275. doi:http://dx.doi.org/10.7596/taksad.v9i4.2784

\section{The Irish Experience of Identity Representation: M. J. Hyland's “Carry Me Down”}

\author{
Dmytro Drozdovskyi ${ }^{1}$, Petro Ivanyshyn ${ }^{2}$, Oksana Prykhodko ${ }^{3}$
}

\begin{abstract}
This paper discusses the philosophical features of M. J. Hyland's novel Carry Me Down (2006) by spotlighting the epistemological paradigm of post-postmodernism. The novel has been discussed in the paradigm of post-postmodernism taking into account the specifics of Irish novel in the second half of the $20^{\text {th }}$ - early $21^{\text {st }}$ centuries (anticolonial explications and the smashed type of identity of the characters). It is stated that Carry Me Down reveals the post-postmodern tendency of seeking for the truth by the protagonist (John Egan) and explaining the nature of human beings in the combination of humanitarian and biophysical. The protagonist of the story has a special superpower of detecting lie in the discourses produced by other characters. The post-postmodern feature is represented in the tendency of rejection of the hybridization between truth and untruth as John physically cannot accept lies (his body vomits and he has a physical discomfort). It was admitted that such a tendency of representing a character with unacceptable forms for lie is also represented in some other British postpostmodern texts, e.g. in The Curious Incident of the Dog in the Night-Time by M. Haddon. In general, the novel exploits the idea of a new way of thinking that can provide forms of existence in the situation of post-truth. The theories of trauma representation in contemporary fiction have been also underlined.
\end{abstract}

Keywords: M. J. Hyland, post-postmodernism, Irish fiction, truth, British novel.

\footnotetext{
${ }^{1} \mathrm{PhD}$, Academic fellow of the Department of World and Slavic Literatures, T. Shevchenko Institute of Literature of the National Academy of Sciences of Ukraine, Ukraine. E-mail: drozdovskyi@ukr.net

2 Professor, Head of the Department of Ukrainian Literature and Theory of Literature, Ivan Franko Drohobych State Pedagogical University, Ukraine. E-mail: pivanyshyn@gmail.com

${ }^{3}$ Ass. Prof., Candidate of Pedagogical Sciences, National Aviation University, Ukraine. E-mail: prykhoxa2017@gmail.com
} 


\section{Introduction}

Carry Me Down is the second novel by the Irish-British writer Maria Joan Hyland, who usually writes under the name "M. J. Hyland" to avoid gender misunderstandings and intolerance in a world the writer still considers to be sexist. She was born into an Irish family in 1968 and spent her childhood in Dublin. The novel Carry Me Down was written in 2006 and was highly acclaimed by literary critics (it was awarded the Hawthornden Prize and shortlisted for the Booker Prize). The novel portrays Dublin and represents the issues of the contemporary (post-postmodern) Irish society.

Moreover, Carry Me Down reveals the tendencies that represent the transformation of postmodernism into post-postmodernism in contemporary Irish-British fiction. This tendency, by the way, is represented, as some scholars state, in the contemporary writings of both Irish and Northern Irish women authors. Contemporary writing

extends and develops the tradition of Northern Irish women's writing which, since the inception of the state, has offered rich and varied engagement with literary form and subject matter. Women have offered the diverse array of perspectives on politics inside and outside the home. They have written from a variety of political stances: feminist and socialist as well across traditional ethno-sectarian divides,

- states Caroline Magennis in the chapter "Northern Irish Fiction" (The Routledge Companion, 2018, p. 190).

Moreover, M.J. Hyland confesses that alongside the political issues she exploited the psychological aspects of her characters in the novel:

I had trouble controlling this urge when I wrote Carry Me Down, which was, in part, driven by a fascination with lying, fascism, the Oedipus complex and, of course, Sophocles' perfect play. But more: the novel was written while the West was going to 'war' with Iraq, and in the cargo-hold there's a theme, enacted in dramatic terms: an attack on absolutism-moral certainty; the arrogance of believing in total certainty. And I was reading Voltaire. But after all that 'thinking' what remains on the surface is a story written in 'one-dollar words' about a boy in love with his mother who'd do anything to keep her close and who wants his father out of the way and who uses his 'gift' for lie detection to deceive and to gain his goal (Bedell, 2006).

The identity of John Egan (the protagonist of Carry Me Down) confronts the essential for a postmodern narrative principle of epistemological doubt (Hans Bertens). On the contrary, John knows the truth of the reality around him because he has the ability (or superpower) to sense people's inner motivations. M. J. Hyland presents a narrative about a teenager

who thinks he has special powers in her enthralling second novel, Carry Me Down.

John Egan is huge, gangling and vulnerable, a 12-year-old child-man on the cusp of adolescence, intensely physically aware but almost wilfully emotionally obtuse.

John believes he has special powers as a lie detector and writes repeatedly to The Guinness Book of Records urging them to test his ability to read minds. $<\ldots .$. . John is adept at noticing what his mother calls 'white lies', he is often incapable of working out what 
prompts people to tell them, of joining the dots of their motivations. His grasp of the world is almost autistic, but it seems to be a willed autism, of a boy who can't see much point in growing up (Bedell, 2006).

The character represents someone with a scholar's investigative and curious mind; he explores life and concludes that lies (perhaps "white lies") are an essential part of the reality around him. However, the representation of "lie-detecting" character in the novel is depicted in a new way. Moreover, the idea of trauma represented in the text is also portrayed as a new issue since the protagonist perceives truth and lies at the biochemical and physiological levels.

\section{Methodology}

In this paper, the hermeneutic approach has been used to highlight the specific features of thinking represented in Carry Me Down by M. J. Hyland.

\section{Carry Me Down: Beyond Postmodernism}

Irish (and British) novels of 2000-2010-s in a special way permeate the psychic component, similar to that which took place in the modernistic period, in which the principles of functioning of the psyche, in particular in terms of perception of time, etc., was evoked.

Post-postmodernism incorporates features of the two previous cultural-historical epochs: modernism and postmodernism. Post-postmodern fiction implies the use of various techniques and means that are possible by the very nature of universal post-postmodern thinking for which there is no limit to the knowledge of reality. Reality is conceived as a multiverse of possibilities, as a special multilevel and multi-layered reality that cannot be understood with only one type of toolkit. In view of this, in the post-postmodernistic novel exploits scientific, metaphysical, and sensual discourses. Cognition of reality seems to be reduced if human thinking is based only on scientific principles or if this knowledge has an emotional and sensory basis. The tools of contemporary sciences, which over the last century have made a fundamental qualitative leap in their development, show the multidimensional reality around human beings; therefore limiting it to knowledge by separate methods would be wrong, as it would not promote human progress in qualitative knowledge about the world and nature. These two problems (knowledge about the world; correlations between the rational and the emotional in a character) are the keys to post-postmodern discourse in Carry Me Down, in which the protagonist (John) represents the post-postmodern way of perceiving the world (skepticism and naivety, rational scientific verification of facts, their collection in the diary + analysis and emotional reactions toward the actions of others). However, at the present stage of the postpostmodern discourse, the novel appears as a form not only of the representation of problems, but an attempt to solve them in the form of alternative realities.

Cognition of truth is an important motive for post-postmodern works and particularly for Carry Me Down. However, this knowledge is a priori doomed to failure because the character does not even have the right tools to understand a phenomenon such as creativity. Speaking about the concept of death, it should be noted that in the perception of post-postmodern characters, this phenomenon has both biophysical/chemical features (I. McEwan's Saturday, M. Haddon's The Curious Incident of the 
Dog in the Night-Time, M. J. Hyland's Carry Me Down, etc.) and mysterious/irrational explanations (the phenomenon of the teenage polygraph in Carry Me Down). An example of this feature is demonstrated by John Egan's perspective that reveals a neo-positivist and skeptical type of worldview.

In the contemporary Irish novel Carry Me Down, the nature of conflict is explained biologically. In the work We Have Never Been Modern, Bruno Latour stresses that the society of the future should adopt the idea of anthropologizing things. It is a matter of fact that external reality must be transformed because particular meanings are given to each object, which is possible when the surrounding reality is anthropologized. B. Latour offers a conception of world perception, in which there is no barrier between humanitarian and scientific knowledge. Technologies are meaningful for B. Latour, as they allow a more intensive manifestation of the human essence, because otherwise they become a source of danger, in which technology has become a continuation of the process of legitimizing the discourse of power. The specific mindset of the characters in the contemporary postpostmodern Irish and British novel (Carry Me Down, The Curious Incident of the Dog in the Night-Time) reveals a new way of connectedness. The human body is conceived as a system of neurons, a system of neuro-somatic regulation; it appears to be an important factor in the general world view of reality. Characters do not usually realize how different parts of their bodies function, but the particular features of the processes determine human behaviour, mood, etc. Neuro-somatic regulation is an important factor in social communication, since the ability of one person to communicate with others essentially depends on the hormonal balance and features of their neurological nature. Latour distinguishes three phenomena that, in his opinion, are important for the twentieth century: naturalization, socialization, and deconstruction. The researcher relates each of these discourses to the names of researchers whose views had a significant influence on the formation of the aforementioned discourse.

The specific psychological characteristics of the protagonist in M. J. Hyland's novel represents the remnants refuse from the principle of postmodern epistemological doubt and provide a belief that a human being has a power to identify the "inner world" of the other people. Using the term "inner world," we mean psychological life of the characters, their intentions and desires. In the novel, we have the representation of the concept of truth that is accepted and identified by John at the physiological level. John Egan is a character who has no doubts about the world around him (i.e., the world of human beings.) Because he has a superpower, the nature of which is not explained in the novel. Moreover, at the end of the story, the character reveals some mental disorders; he has strong emotions and displays such phenomena as aggression, mental instability, etc. Having the superpower of being a "polygraph" does not imply possession of a super-mind that is resistant to the effects of the world around him.

The post-postmodern tendencies of M. J. Hyland's story are the following:

1) From the historical perspective, the novel was written after 2000, which means that it represents a cultural tendency identified by British cultural and literary theorists as postpostmodern (according to The Routledge Companion);

2) Psychologically we have a character who has no doubts about what is true; 
3) The narrattee provides the sort of writing that does not give readers any clue to verify the constructed reality at the end of the story - whether it is true or is a product of the imagination and a result of 'true' reality being displaced by the psychological mechanisms of John's psyche;

4) The principles of connectedness between the characters define the problematic issues of the novel (constructed stereotypes, living in the reality of simulacrum, religious and faith problems, etc.); the psychological level of the novel (connectedness between John and his family, between John and his classmates, between John, his family and neighbours and other people on the street, etc.) becomes an important part of the text reception;

5) The human being in the novel is exploited and portrayed as a combination of physical (body functions are rediscovered or re-thought, however, they are not explained to the readers and some disorders or superpowers are portrayed in a physical way but with no explanation of how this works on the biochemical or micro and metaphysical level (religious beliefs, faith, supernatural powers).

Post-postmodern text represents a reality that imitates real life by outlining some key social, political, and psychological problems that are discussed in society and has a correlation with real issues. True human emotions and real stereotypes, misunderstandings and cultural prejudices, religious confrontations and mental disorders make up the map of issues represented in the postpostmodern text's intended focus on the "true reality" that should be re-thought and discussed.

John Egan is a teenager who represents a new type of post-postmodern identity and its narrative description. He can say whether statements are true or false. John's ability is represented in the novel Carry Me Down as a superpower, however, this literary representation reveals the traditional problem exploited in Irish fiction. Although M. J. Hyland was born in London in 1968, she spent her childhood in Ireland and John's father, dreams about Dublin Trinity College. This novel is a representation of a text about Irish identity, Irish people, Irish Catholicism, etc.

The inability to tell the truth is perceived in the novel as a source of trauma.

A traumatic event can be defined as a painful occurrence, but so intense that it exceeds our capacities to experience it in the usual ways. It disrupts time and history, breaks through the categories we use to take in the world, and seems to be registered in our memories in forms unlike those used to register conventional experience. This atypical memory is sometimes called traumatic memory to differentiate it from our usual narrative memory. $<\ldots . .>$.

The reception of a traumatic event always implies a temporal dislocation since it ruptures the narrative continuity between past and present: that is, at the moment when it occurs, the traumatic event is not actually experienced by the subject (del Río Álvaro, 2010, p. 4).

As some scholars underline, trauma is an essential part of the $20^{\text {th }}$ and $21^{\text {st }}$ centuries Irish fiction, however, M. J. Hyland has exploited a new type of trauma that does not have psychological/mental symptoms but is physical in nature. As Ruth Leys explains, the horror of trauma reveals the situation when the mind: 
cannot register the wound to the psyche because the ordinary mechanisms of awareness and cognition are destroyed. As a result, the victim is unable to recollect and integrate the hurtful experience in normal consciousness; instead, she is haunted or possessed by intrusive traumatic memories. The experience of the trauma, fixed or frozen in time, refuses to be represented as past, but is perpetually re-experienced in a painful, dissociated, traumatic present (Leys, 2000, p. 2).

Thus, the inability to tell the truth is the product of Irish history represented in the novel in the characters discourse, whether members of John's family (father and mother) or the neighbours and strangers who they (John and his father) meet on the streets of Dublin. As the scholars underline:

The concept of intimacy has a broad application, and intimate life can be constructed, experienced and represented in a variety of ways. <...>. This imperative is particularly keen in fiction grappling with a 'post'-conflict past. Within the stories under consideration, truths unspoken feature heavily and the inability to fully articulate plays a role in several (The Routledge Companion, 2018, p. 191).

The first dramatic episode in the novel discussed (when the father is killing kittens in the bathroom) reveals the motif of cruelty that exists in people who want to be polite and tolerant but who have a destructive urge deep inside them. This idea is a representation of the concept of the damaged psyche expressed in this kind of behaviour. The Irish identity of 40-50 years old people reveals the problem of "untold truth" that results from the impossibility of expressing yourself.

Seeking truth is a part of the post-postmodern motif explained in David Shields' manifesto "Reality Hunger". In the chapter "Autobiografiction" in The Routledge Companion, Timothy C. Baker analyses David Shields's "Reality Hunger" manifesto (2010) drawing readers' attention to the fact that what is real in fiction is not important but what can cause the experience of "authenticity" is important (cit. in The Routledge Companion, 2018, p. 48). David Shields uses the terms "deliberate unartiness", "the difference between fiction and non-fiction", etc.

Timothy C. Baker summarizes this as "James Wood comments in a review of Sheila Heti's How Should a Person Be? (2012) Shields' title is particularly apposite:

'[r]ealism is perpetually hungry [...] because no bound manuscript can ever be 'real' enough' (Wood 2012). In a variety of forms, ranging from romans á clef and fictional autobiographies to fiction presented in the form of autobiographies, diaries, and memoirs, as well as texts that problematize all categorical distinctions, contemporary writers constantly renegotiate the value of the 'real'" (The Routledge Companion, 2018, p. 48).

Sophie Vlacos, the author of the chapter "Realisms" in The Routledge Companion, discusses the concept of Object Oriented Ontology (The Routledge Companion, 2018, p. 101) as a new vector for a literary realistic paradigm of post-postmodern fiction. The ontological mode of reality becomes an essence in the post-postmodern literary paradigm in contemporary British fiction. The ontological mode exploits the connections between the characters and the anthropocene phenomena taking into account the concept of "inner interior" which means the deeper bonds between things and human 
beings that cannot be explained by the traditional logical paradigm or by using the traditional methods of explanation.

Granted the diversity of approaches and mediums covered by this general inclination to think beyond the subject, 'contemporary realisms' seems an appropriate flexible term through which to explore their commonality and their literary repercussions. The suitability of this ambidextrous term is confirmed by the rise of a philosophically incongruous and yet historically consistent wave of literary humanism of 'New Sincerity', a mode of literary realism devoted to the material and phenomenological reality of human experience impelled by a similar fatigue with poststructuralist preoccupations (The Routledge Companion, 2018, p. 101).

Thinking of these words by Sophie Vlacos, we have in my mind Olga Tokarchuk's recent Nobel lecture. The Polish author mentioned in her Stockholm speech (December 2019) the term "parable realism". Moreover, let us remind you also of R. Rucker's "A Transrealist Manifesto" in which the American scholar and writer proposes another form of "contemporary realisms." ${ }^{4}$ In this way, S. Vlacos's position enables the term (or paradigm) that coordinates various academic views and writers' manifestos regarding the new form of reality and its representations. Furthermore, this term 'contemporary realisms' demonstrates the importance of realistic tendencies and modes in contemporary fiction.

As British scholars consider, "eighteen years after Brown's essay the discussions on the material essence of the things have become deeper" (The Routledge Companion, 2018, p. 100). Sophie Vlacos takes into account Bill Brown's manifesto "Thing Theory" (2001). The mentioned discussions have unfolded the interest in realism and its representations in post-postmodern fiction.

Contemporary fiction exploits the motif of displacement.

The term 'displacement' can name an affective state, a psychological mechanism and a physical experience. The interaction between these meanings of the word produces much of its richness and perhaps explains the frequency with which it occurs in contemporary scholarship attempting to grapple with the movement of people around the globe today, and with the legacy of the migrations of the past, both of which have involved violence, coercion and exploitation as well as hope, human ingenuity and the creation of new bonds, communities and cultures" (The Routledge Companion, 2018, p. 239).

Besides this long but effective definition (which can be of course developed and unpacked), Emily Hogg, the author of the chapter "Displacement", writes that

Most obviously, displacement refers to the experience of being out of place geographically. <...>

The concept of 'multiple displacement' - referring to a series of proliferating, different displacements, with shared historical roots - also has resonance beyond the Palestinian case, and it is useful to think about this term in relation to Dust, which is set in Kenya (The Routledge Companion, 2018, pp. 239-240).

\footnotetext{
${ }^{4}$ For more details read: http://www.rudyrucker.com/pdf/transrealistmanifesto.pdf
} 
Displacement as a theoretical concept that outlines and represents one of the key vectors for the transformation of the British novel has been analysed in The Routledge Companion to Twenty-First Century Literary Fiction (The Routledge Companion, 2018, pp. 239-249) by Emily J. Hogg. In the chapter, "Displacement", the author exploits the concept of multiple displacement based on the novel Dust (2014) written by Yvonne Adhiambo Owuor. Migration, terrorism, and refugees are images that determine the thematic spectrum of contemporary British novels written in the 2000s, which once again reveal the transgression motif inherent in the post-postmodern novel and relate it to the transculturation paradigm.

The shifting of cultural patterns, experiences, interaction of one type of identity with another is represented in M. J. Hyland's novel in which characters embrace the views inherent in the Global Care doctrine, in particular in terms of developing shared responsibility.

The discourse of the otherness is an essential element to unfold the questions of transculturalism in contemporary Irish fiction. The process of transculturation involves interchange and enrichment for all participants in the space of contacts. Moreover, "connectedness" is an important feature of the post-postmodern fiction. Analysing Ali Smith's novels, Monica Germaná states:

Significantly, while placing emphasis on the critical state of human relations in the twentyfirst century, Smith's fiction also emerges as strongly life-assertive and redemptive, replacing the solipsistic of contemporary living with a new kind of emphatic connectedness that, arguably, constitutes a clear departure from the postmodern disaffection (The Contemporary British Novel since 2000, 2018, p. 100).

The scholar defines this new feature as an important element in transformations of the postmodernism into post-postmodernism. While postmodern characters revealed that state of tranquillity as a way to escape the outer chaos, post-postmodern characters are ready to be a part of the confrontation in the world trying to understand the deep (genetically determined, metaphysical) essence of such disorder that leads to human misunderstandings and conflicts. Post-postmodernism exploits the importance of true feelings and emotions, and encountering otherness provides an opportunity for both parts of the transcultural situation (even it is painful and unpleasant mentally or emotionally). In the novel "Dust", the characters

Ajany and Odidi, struggling with this hostile school environment and with tensions in their family, respond with dreams of movement and migration. <...>. The language of home, homelessness and longing is repeated in Selene and Hugh's story. Selene experiences an intense feeling of displacement in Kenya. <...>. Ajany and Odidi, on the other hand, are citizens of the post-colonial nation-state - their sense of belonging is not ethically compromised in the way that Hugh's is. Nonetheless, because the novel uses repeated words and phrases to link Ajany and Odidi's story with Hugh and Selene's, the reader becomes aware that Ajany and Odidi's homelessness is not simply a free-floating or individual sense of being dislocated or disconnected (The Routledge Companion, 2018, p. 241). 
Anyway, for many reasons the concept of connectedness is associated with the postpostmodern discourse, which is oriented to depict the deep pain and feeling of loss and disorientation that the characters have and express because of the disordered world to which they belong and that a priory cannot be their home as a comfortable place of safety.

\section{Traumatic Truth and Lies}

M. J. Hyland unpacks the idea represented in J. Johnston's fiction, e.g. The Old Jet (1979) and How Many Miles to Babylon (1974) related to the concept of the multifaceted nature of Irish identity represented in social communication.

The contemporary Irish novel registers a similar dialectic between remembrance and forgetting, between disclosure and silence. In the opening lines of Anne Enright's The Gathering (winner of the Man Booker Prize for Fiction 2007), the protagonist narrator states: "I need to bear witness to an uncertain event". And bear witness she does, thus joining other fictional voices in many Irish novels that have recently testified to insanity, dysfunctional families, endemic poverty, sexual abuse, incest, rape or vicious sectarian violence (del Río Álvaro, 2010, p. 7).

Ireland's colonial history and the struggles for the independence resulted in a fear of telling the truth and acting in a way that reflects the desires of the characters. As the scholar notes: "Uncertainty, violence, fragmentation, discontinuity... These are probably the hallmarks that $<. . .>$ give Irish history a "catastrophic" dimension <...>: successive waves of conquest and colonization, bloody wars and uprisings, traumatic dislocations" (del Río Álvaro, 2010, p. 3).

Caroline Magennis analyses contemporary post-postmodern Northern Irish fiction and draws attention to the point that, for example, in Jan Carson's "Settling", the main issue is related to the "traditional emigrant narrative of a Northern Irish couple who move to England for work. However, soon we see that the story has a complex engagement with intimacy of the past and present. Often, their relationship has false starts and failures to connect" (The Routledge Companion, 2018, p. 194).

The historical "suppression" has marginalized the necessity of telling the truth that is exploited in Carry Me Down (by both men and women). The inability to speak the truth causes breakdowns and failures in John's communication and the impossibility of "spring" in an Irish society that still lives in the paradigm of "untold" and "hidden" that generates aggression and miscommunication between the agents. People around the protagonist reveal forms of cruelty (in the street by passing strangers), e.g. because of John's physical characteristics. His father is short and he becomes the object of teasing by other people. C. Magennis states: "A political engagement is expected of texts from countries with a recent history of violent conflict $<\ldots .$. . This is understandable as the private and the public have been tied to each other in complex, ambiguous ways in Northern Irish culture" (The Routledge Companion, 2018 , p. 192). This tendency occurs in contemporary Irish writings and demonstrates the characters' desire to live in a country of truth where people have an equal right to have an opinion and to say what they think to others. In this way, John's physical inability to accept falsehood can be explained hermeneutically in that he is a person of the new era and he has a new way of thinking based on the 
postcolonial way of perceiving the world. For him, telling the truth is an essential part of creating a society of healthy and happy people.

Moreover, the episode of John's confrontation with his mother is a representation of an agony motif determined by the lack of truth in the society. Mother, who is one of the closest people to John Egan (genetically) is not a part of his personal (psychological) environment.

The social sphere in the novel outlines the problem of miscommunication and the trauma of physical pain it causes. For the first time in contemporary Irish fiction, the phenomenological matter of truth and lies is represented in a post-postmodern that relates to the tendency to medicalize and the representation of the human being as a biochemical entity (for example, see also lan McEwan's "Saturday" or "Amsterdam", where the discourse of the narration is totally medicalized). On the other hand, the motif of truth-seeking is represented in $20^{\text {th }}$ century Irish fiction. For example, it is exploited, as mentioned earlier in this paper, by Jennifer Johnston's novels portraying Irish characters as those who have a kind of multifaceted identity. Being controlled and colonized by the centre of the Empire (England) for many years, as J. Johnston demonstrates, the Irish characters have "three faces": they speak in one way, think in another and react in a third way.

In creating her character M.J.Hyland shows the tendencies that demonstrate the transformation of postmodern sincerity into post-postmodern sincerity revealing the new model of "new sincerity" as a philosophical and socio-psychological phenomenon. For Egan, knowing the truth is a physical necessity: when he hears statements that are untrue, he vomits, providing a physical response to what is happening around him. The inability to accept truth has a physical and psychological impact, as the confrontation with reality shows when other characters lie and make John feel a psychic toll, a mental disorder as the result of his inability to understand why people lie. Even his grandmother, who in the novel maintains order in the family, lies and this all upsets Egan and makes him feel sick.

Carry Me Down provides a medicalised look at the nature of the character's mind as linked to his body. Being a polygraph-teenager, John feels a constant physical pain that cannot be explained in the rational medial paradigm; however, it is a medical problem.

M. J. Hyland has said in some interviews that she wanted to create a "universal" character and a novel with no particular memory, geography, location or cultural connections.

I wanted both Carry Me Down (2006) and This Is How (2009) to seem not to have been written at all. Instead, stories that might have come from the cave: written in a single voice belonging to no fixed era, place, gender, or race. If this approach works, the voice should ring as a universal-perhaps timeless-voice; a truthful voice emptying its guts and giving up its woes (Bedell, 2006).

However, John's father wanted to attend a particular Dublin College and the reality around John exploits the psychological and social specifics of the contemporary Irish society.

Thus, Carry Me Down explains the post-postmodern paradigm of the contemporary fiction demonstrating that new characters are not satisfied with living in the reality-based on total relativity (as it generates lies). The reality around John hurts him and makes his body feel pain and be 
intoxicated. That "toxins" determine the crime is, however, represented in the novel in a specific form. Readers cannot be absolutely sure whether what happens between the son and his mother is a crime or simply the result of a mental disorder, so that John has only created in his mind the new kind of reality that replaced the "real" one.

At the end of the novel, we notice the realization of the displacement motif represented as a part of the narrative and as a psychological phenomenon that makes it difficult to verify which kind of reality is real. In this way, we see one of the key features of the post-postmodern narrative that I have investigated in my previous researches: the epistemological inability to distinguish real and unreal as even the "real reality" exists in a character's perception.

John reveals the kind of mind that has a super-ability to explore reality and distinguish the truth. This ability correlates with some other British and American fiction in which we have characters who perceive reality in a rational way concentrating only on facts. Christopher, the protagonist in the novel The Curious Incident of the Dog in the Night-Time by Mark Haddon states that only mathematics can provide a total understanding of reality, however, the teenager (with Asperger's syndrome) does not neglect the possibility of God's existence (the metaphysical phenomena).

Besides, his fanatical and exaggerated faith in mathematics makes him a character of the postpostmodern kind: for him, it is important to know the truth and he cannot understand the behaviour of neighbours and his family who always lie to him. Lying is represented in both novels as an essential component of the discourse used in them, however, the new characters who have minds of a special type (autistic or lie-detecting) find the communication considered normal by society unsatisfactory.

\section{John Egan as an Alien}

M. J. Hyland uses the grotesque technique to underline the gaps between John and his environment: he is an "alien" at home and college.

In addition, the religious Catholic education in the novel is also based on lies, as the students need to comply with the restrictions and obligations regardless of their inner needs. In this way, the author shows how schools and the college system in general support the idea of falsity as a state policy: from childhood, boys and girls are supposed to be not themselves but present a kind of social identity demanded by the social rules. John feels pain and physical discomfort when speaking to his schoolmates.

According to C. Magennis,

despite a growing support for the procedure in Northern Ireland, the reproductive rights anathema is so strong that she cannot voice her experience. Caldwell paints a complex emotional picture where intimacy in the present is in dialogue with intimacy of the past. She has been given a narrative for how this most intimate of scenarios will play out: only she has this kind of knowledge now" (The Routledge Companion, 2018, p. 196).

M. J. Hyland is critical about Irish Catholic education demonstrating that this way of teaching is old; it does not fit the needs of the new generations who are the "children of the pragmatic age". Students of the college really do not demonstrate a deep understanding of faith and religious belief, 
for they are aggressive, cunning, lazy, pragmatic, etc. The new generation of young men and women live in a world of pragmatism and have little in common with spiritual life of their parents and older generations. However, people who have gone through a Catholic education may also be cruel and a source of pain.

For example, John's father does not understand that his actions are, in fact, killing, taking the kittens' lives. Grandmother, who is the most polite person with John, does not understand his needs either and his inner life is represented fully only in his "The Diary of a Lie". Every single day John identifies all the examples of lying that he encounters in his daily life, and the diary is a representation of the scholar's mind that explores the reality and summarises the results of the experiment. John's experiments are connected with the idea of whether a person can live without lying, and John's answer is mainly negative as all the people around him accept and produce lies as a part of their daily routine.

Existential and religious solitude for John Egan is a form of constructing an identity that seeks realization not on the intersections with collective identity (community identity) but another level.

In Carry Me Down, the character does not accept most of the rules, ethics, and conventions of the world in which he lives. John does not understand why everyone around him lies, why even the relatives who care about him lie. The teenage "polygraph" is a post-postmodern version of identity that visualizes a number of new problems compared to postmodern discourse. The first problem is related to the new type of communication of postmodern characters. Meetings with "others" are traumatic and suggest that polygraph characters like John live in a world of reflections and quests that demonstrate their clear purpose, values, aspirations, and impulses. Such characters as John do not need people from the outside world to fulfil their aspirations. The world around John Egan is built on simulacra (lies) and not facts, real emotions, and true feelings. Setting down meetings, phrases, and behaviours of other people in the daybook (diary) enables John to understand the world as the reality of lies. John's "The Diary of a Lie" is a form of constructing a real world.

Post-postmodern characters like John (he wants to know the true reality and does not believe in the positive role of epistemological doubt and ambiguity) avoid emotional impulses. John Egan seeks to perceive reality as mechanistically as possible, which makes it possible to understand reality as objective. Surroundings push the hero to the loss of inner mental equilibrium. In post-modernist novels, time is devoid of emotional designation.

John needs to accumulate experience, each element of which he places in his diary, designating a particular box for people and objects. In the post-modernist novel, it occurs in relation to objects of an inanimate nature that give the character much more focus on self-discovery than on communication with other characters, even his or her closest relatives. "Intimacy can be a disruptive force on a continuum - from the smaller ruptures of awkward lovemaking to the larger problems of abuse and violence meted out by trusted partner or family member" (The Routledge Companion, 2018, p. 191).

John's existential and religious loneliness arises as a result of connections between faith, the church, the college, and God formed in the bosom of the Catholic Church by the parameter of "sincerity". Existential loneliness is the starting point for knowledge of reality as a potentially multiple 
phenomenon in which we observe the interaction of the physical and metaphysical (John does believe in the Supreme Being), however, he does not understand why God made this world so mendacious. M. J. Hyland criticizes Catholicism because hypocrisy sown within him in the 21st century and the church did not influence the formation of true nobility and sincere faith in people.

\section{Conclusions}

In Carry Me Down, we have a new, representation of issues compared to the postmodern, primarily related to the portrayal of the individual identity of characters. This novel is discussed in this paper as an example of a post-postmodern text that represents features showing the transformation of postmodernism into the new cultural phenomenon that goes beyond it. The protagonist of the story has a superpower that helps him seek the truth and identify lies. John Egan accepts the truth on the unexplained biochemical psychical level; however, this ability to identify the truth presents more problems for communication and self-understanding. John reveals problems with religious faith because he does not understand how God could have created a world based on lies.

Besides, M. J. Hyland creates her story using techniques of shifting real and imagined, so that at the end of the novel (after the conflict between John and his mother) the readers see the picture that may be a result of John's psychological displacement and an example of his mental resistance to understanding what really happened. The character who lives without any epistemological doubts about the truth (he is a human being with polygraphic abilities) becomes mentally ill and confused because of a lack of understanding that leads to a powerful emotional clash and confrontation with his family and other people in the story.

The protagonist of the post-postmodern narratives discussed does not need a collective identity to crystallize his or her own identity; instead, forms of communicative interaction with the Other are often a factor in the imbalance of John's worldview and a source of psychological and physical pain. The character's existing neurophysiological features and neurological disorders (John cannot physically cannot perceive falsehood) give grounds for claiming that there is a special type of narrative identity in Carry Me Down. John seeks to understand reality as a system of clear laws without lies. He writes a diary in which he collects all the stories of lies, setting them down and providing a database of instances of lies in society. The superpower does not make the protagonist happy and does not harmonize his world with the reality around him. What is more, this power becomes self-destructive because the collective identity of the people in the novel implies the existence of lies. John understands that the world is based on simulacra and false statements but he cannot change this position. Besides, the unique ability of the character results in the destruction of religious belief and lack of faith because John understands that this world does not imply God as a Being who does not lie. Truth is portrayed in the novel as a factor capable of creating a new kind of society in the future. However, Irish society is not ready for such major drastic transformations because its everyday "agenda" is based on prejudices and stereotypes, etc. created in the past that avoid the necessity of absolute truth and seeking it. Carry Me Down in a critical way discusses the Irish inability to be sincere; however, the author has created a protagonist with a new kind of mind that is beyond cultural/religious/social prejudices and stereotypes. 


\section{References}

Bedell, G. (2006). "I'm a human lie detector, honest". The Guardian. April 2006. Retrieved from https://www.theguardian.com/books/2006/apr/23/fiction.features4

Del Río Álvaro, C. (2010). "Trauma Studies and the Contemporary Irish Novel”. In D. Clark \& R. J. Álvarez (Eds.), In the Wake of the Tiger: Irish Studies in the Twentieth-First Century, (pp. 3-16). Oleiros: Netbiblo.

Doyle, M. (2015). "Putting Irish Women Writers Back in the Picture". Irish Times. 23 February. https://www.irishtimes.com/culture/books/putting-irish-women-writers-back-in-the-picture$\underline{1.2113897}$

Drozdovskyi, D. (2019). Philosophical and Genological Features of English Post-Postomodernistic Novel: Typological Characteristics. English and American Studies, 1(16), 150-159. DOI: https://doi.org/10.15421/381921

Drozdovskyi, D. (2019). Postmodernism vs Post-Postmodernism: Philosophical Distinctions (in the Contemporary British Novel). Philological Tractates, 11(3-4), 32-40. DOI: https://doi.org/10.21272/Ftrk.2019.11(3-4)-4 [in Ukrainian].

Drozdovskyi, D. (2019). Psychological Identity of Characters of British Post-Postmodern Novels: Discourse of Ego-Literature. Zhytomyr Ivan Franko State University Journal. Philological Sciences, 1, 4855. DOI: https://doi.org/10.35433/philology.1(89).2019.48-55 [in Ukrainian].

Graham, B. (1997). "The Imagining of Place: Representation and Identity in Contemporary Ireland". In B. Graham (ed.), Search of Ireland, (pp. 192-212). London and New York: Routledge, 192-212.

Hyland, M. J. (2006). Carry Me Down. Edinburgh: Canongate.

Jordan, J. (2015). "A New Irish Literary Boom: The Post-crash Stars of Fiction". The Guardian. 17 October. https://www.theguardian.com/books/2015/oct/17/new-irish-literary-boom-post-crashstars-fiction

Latour, B. (1993). We Have Never Been Modern. Cambridge, Massachusets: Harvard University Press.

Leys, R. (2000). Trauma: A Genealogy. Chicago and London: The University of Chicago Press.

Smyth, G. (2001). Space and the Irish Cultural Imagination. Basingstoke and New York: Palgrave.

The Contemporary British Novel since 2000 (2017). Edited by J. Acheson. Edinburgh: Edinburgh University Press.

The Routledge Companion to Twenty-First Century Literary Fiction (2018). Edited by D. O'Gorman and R. Eaglestone. London-New York: Routledge.

Tracy, R. (1999). "Undead, Unburied. Anglo-Ireland and the Predatory Past". Lit: Literature, Interpretation, Theory, 10.1, 13-33. 